Mitteilungen der Österreichischen Geographischen Gesellschaft, 162. Jg., S. 369-395

(Annals of the Austrian Geographical Society, Vol. 162, pp. 369-395)

Wien (Vienna) 2020, https://doi.org/10.1553/moegg162s369

\title{
Multiple Dimensions of Mediatised Translocal Social Practices. A Case Study of Domestic Migrants in Bangladesh
}

\author{
Harald STERLY and Patrick SAKDAPOLRAK, both Vienna [Wien]* \\ Initial submission / erste Einreichung: 05/2020; revised submission / revidierte Fassung: 10/2020; \\ final acceptance / endgültige Annahme: 12/2020 \\ with 2 figures and 1 table in the text
}

\section{CONTENTS}

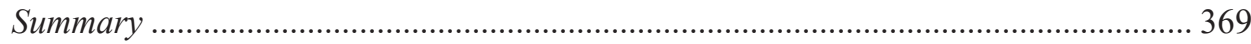

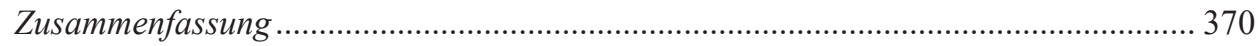

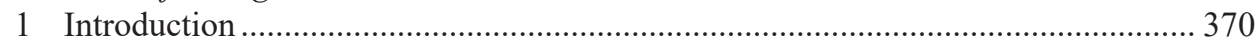

2 Mediatised translocal practices - a brief overview .............................................. 371

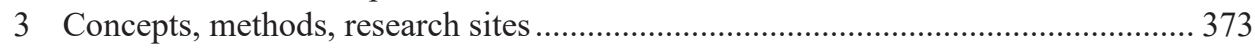

4 Types of mediatised translocal social practices................................................ 375

5 Mediatisation as overcoming constraints by drawing on media affordances........... 386

6 Contextualising mediatised practices in translocal livelihoods................................. 388

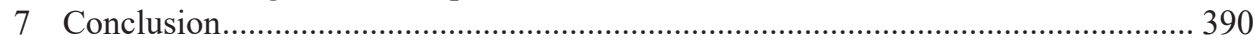

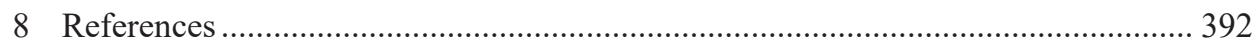

\section{Summary}

In the past decades, migration and translocal forms of living, including the spatial separation of households and families, have become everyday reality for almost a billion people. At the same time, mobile information and communication technologies, and especially mobile phones, have spread rapidly and are now accessible for many, even in poorer contexts in the Global South. The article combines practice-theory with approaches from media studies to examine how these two large themes intersect. It shows how the adoption of mobile phones by rural-to-urban labour migrants in Bangladesh is changing their trans-

\footnotetext{
* Dipl.-Geogr. Dr. Harald Sterly, Senior Scientist, University of Vienna, Department of Geography and Regional Research, Universitätsstraße 7/5, A-1010 Vienna, Austria; Prof. Dr. Patrick SAKDAPOLRaK, Full Professor, University of Vienna, Department of Geography and Regional Research, Universitätsstraße 7/5, A-1010 Vienna, and International Institute of Applied Systems Analysis (IIASA), Schlossplatz 1, A-2361 Laxenburg, Austria._Emails: harald.sterly@univie.ac.at, patrick.sakdapolrak@univie.ac.at.
} 
local social practices, discusses key reasons for these changes, and their implications for translocal livelihoods and lives.

Keywords: Translocality, migration, mediatisation, mobile phone, social practices, Global South, Bangladesh

\section{Zusammenfassung}

\section{Multiple DimenSIONEN MEDIATISIERTER TRANSLOKALER SOZIALER Praktiken. Eine Fallstudie ÜBer Binnenmigranten in Bangladesch}

Migration und translokale Lebensformen, einschließlich der räumlichen Trennung von Haushalten und Familien, sind in den vergangenen Jahrzehnten für fast eine Milliarde Menschen alltägliche Realität geworden. Gleichzeitig haben sich mobile Informationsund Kommunikationstechnologien, insbesondere Mobiltelefone, rasch verbreitet und sind heute für viele Menschen auch in ärmeren Kontexten im Globalen Süden zugänglich. Der Artikel verbindet Praxis-Theorie mit medienwissenschaftlichen Ansätzen, um zu untersuchen, wie sich diese beiden großen Themen überschneiden. Wir zeigen, wie die Einführung von Mobiltelefonen durch Arbeitsmigranten vom Land in die Stadt in Bangladesch deren translokale soziale Praktiken verändert und diskutieren die Hauptgründe für diese Veränderungen sowie ihre Auswirkungen auf die translokalen Lebensgrundlagen.

Schlagwörter: Translokalität, Migration, Mediatisierung, Mobiltelefon, soziale Praktiken, Globaler Süden, Bangladesch

\section{Introduction}

While there is a considerable body of research on the mediatisation of various social practices of international migrants, especially from the Global South in the Global North (for example MAdianou and Miller 2011; CHIB et al. 2014 on mobile phone parenting of Filipina overseas workers; or Siegel and Fransen 2013; Nyanhete 2017 on international remittances), there is much less research on these processes at the scale of domestic migration in the Global South (with some exceptions, for example on the role of information and communication technologies for migrant family life in China, e.g. LAM 2013). This is surprising because of two reasons: on the one hand, for many millions of domestic labour migrants and their families, who outnumber international migrants by far, the instant and distant connectivity that mobile phones afford, can be considered a game changer for their daily lives and wellbeing. And on the other hand, mobile communication technology has become affordable and widespread (with an average penetration rate of 108 percent globally, and 104 percent in developing countries in 2019; cf. ITU 2020). Thus, also less wealthy and educated groups have access to and are using mobile phones and increasingly, but still to a lesser extent, also broadband and internet.

This article addresses the intersections between mediatisation and translocality (GREINER and SAKDAPOLRAK 2013) and contributes to the literature on mediatised translocal prac- 
tices. We follow COULDRY and HePp (2013) in their definition of mediatisation as processes of interrelated changes of media and communication on the one hand, and culture and society on the other; they distinguish two strands of research within mediatisation research, one institutional-systemic, and one more social-constructivist - of which we see ourselves in the latter. Our main objective here is to show how mobile phone usage facilitates and at the same time changes translocal practices between domestic migrants and those left behind. The article adopts a social practice approach and focuses on mundane everyday practices and strategies. It is based on multi-sited empirical research, carried out over a period of six months in total, between 2011 and 2013, in two villages in Northern Bangladesh and in Dhaka. Although there has been further and stark increase in the proliferation of mobile phones, the mechanisms how and why the uptake of mobile phones lead to specific changes in translocal practices can be explored and explicated well with these data.

The mediatised translocal practices of domestic migrants will be exemplified for the case of Bangladesh, where - like in many other countries - migration as well as the mediatisation of communication are two processes that are important for millions of peoples' lives, as almost 10 percent of the population are domestic migrants (13.5 million out of 143 million inhabitants 2010; BBS 2015). Most of these migrants originate in what can be characterised as poor rural contexts, and have as destinations the urban centres, pursuing income opportunities in formal and informal employment and economic activities. Migrants and their households at the places of origin remain highly connected, both socially and economically, and this creates a dense network of translocal social constellations between places and people. But Bangladesh has also seen a tremendous rise in access to mobile communication: Although not being closed altogether, the digital gap, for at least basic voice and text message connectivity, has decreased significantly especially between 2000 and 2015 (from 0.22 subscriptions per 100 inhabitants to 84.1; ITU 2020). Thus, for millions of migrants and their family members at places of origin, a dramatic change of connectivity has occurred in a relatively short time.

In the following section, we will first provide a brief overview on the research on mobile communication and mediatisation of translocal practices that the article is embedded in. The following section highlights the key concepts and the methodology used in the research process, as well as a short description of the research sites. In section 5, the empirics part, we systematise essential mobile phone usage practices in the translocal domain, and in the following parts, we interpret the mediatisation of these practices and what that means for the translocal lives of migrants.

\section{Mediatised translocal practices - a brief overview}

There is a substantial research and literature body on information and communication technologies (ICT) and mobile phone usage of migrants, with a variety of disciplinary backgrounds. Interestingly, although the topic is relevant for Geography, there are only few contributions from Geographers here. In the following, we will cover two aspects: the mobile phone usage of migrants in general, and the role of mobile communication for translocal lifeworlds. 
Literature on mobile phone usage by migrants in general includes a range of topics, among them: the role of mobile phone usage for the integration and acculturation of migrants at places of destination (e.g. Coles-Kemp et al. 2018; Gordano Peile and Ros HíJAR 2016; JOHNSON 2013); the role of mobile phones and ICT for migrants to facilitate and navigate their daily lives at places of destination (e.g. HARney 2013; KAUfMAnN 2018); migrants' mobile phone appropriation and adoption (e.g. ARICAT et al. 2015; DE BRUIJN et al. 2010); the usage of mobile communication by migrants for self-organisation and political activism (e.g. Peng and CHOI 2013; QIU 2014), as well as the diaspora organisation at places of destination (e.g. LOPEZ 2017; BARBER 2008).

For our focus in this article more important, there is also a growing body of literature which addresses the importance of mobile communication for translocal and transnational connectivity, exchange and practices (VERTOVEC 2009). These include for example the role of ICT and mobile communication for migration decision making, and for managing the process of migration: KIRWIN and ANDERSON (2018) and Frouws and BRENNER (2019) for example find that West African migrants to Europe use social networks and ICT to carefully plan their migration routes. BoAs (2020) shows how rural dwellers of coastal Bangladesh use mobile communication to stabilise translocal networks and thus facilitate domestic mobility as a disaster response strategy. A specific type of research deals with refugees and how they use mobile communication, for example to organise their trajectories and journeys (SCHAUB 2012 on mobile phone use by migrants crossing the Sahara desert; ZIJLSTRA and VAN LIEMPT 2017 on the role of mobile technology for decision making on destinations, routes and for financing the journey of irregular migrants; or DEKKER et al. 2018 on the role of social media for destination decision making by Syrian asylum seekers).

As remittance sending is one of the most important translocal practices (RATHA 2003), it is not surprising that there is also research on the effects of mobile communication on various aspects: on the changing expectations of remittances (for example TAZANU 2015 on increasing pressure on Cameroonian migrants in Germany to remit), on the volume, frequency, and diversity of remittance flows (see ALAMPAY and MosHI 2018 for a comprehensive review on that) and of course the role of mobile banking (e.g. KIKULWE et al. 2014 on the effects of mobile money transfers on livelihoods in Kenya and SEKABIRA and QAIM 2017 in Uganda; Kusimba et al. 2016 and OJONG 2016 on the relation between mobile transfers and social networks in Kenya and Cameroon, respectively).

Another important research field covers the role of mobile communication for the management of migrants' family affairs and relations (e.g. AHLIN 2020 on frequent calling as enacting good care within transnational Indian families; CUBAN 2014 on joint and distant learning practices in transnational families; MADIANOU 2016 on 'ambient co-presence', the pervasive and constant digital connectedness of UK-Filipino families; or PORTER et al. 2018 on how migrants and their families in Africa manage relational and emotional proximity). A subset of this topos deals specifically with remote or mobile parenting, with a notable cluster of literature on international (women) migrants from the Philippines and how they employ ICT to maintain their motherhood at a distance (e.g. CABANES and ACEDERA 2012; MAdiAnOU 2012; CHIB et al. 2014), and on similar issues among domestic migrants in China (LiU and LeUng 2017; To 2018). 
Thus, while there is considerable scholarly work on mediatised practices of migrants in general, there is less so on the mediatisation of specifically translocal practices, and the literature on that seems rather focused on single specific aspects, such as remittances, family relations or parenting. What is less present is a more encompassing perspective that captures the diversity of interactions, transactions and mobilities that characterise translocal practices and everyday life. This paper aims at taking such a wider look at the range of translocal practices that are relevant for the lives of rural-to-urban migrants in Bangladesh. Although translocal practices of international and domestic migrants do not differ necessarily to a large extent, the mediatised translocal practices of domestic migrants receive far less attention, thus we see an important contribution here.

\section{Concepts, methods, research sites}

In the following, we will introduce the key concepts and theoretical embedding, the general research approach, and the employed methods, and briefly describe the research sites in Bangladesh.

\section{Concepts}

The key concepts used in this study are social practices, translocality, affordances and constraints. Social practices are here understood as socially structured, routinised actions, including thinking and understanding, communicating, moving, using the body, objects and technology (see also RECKWITZ 2002). We understand practices and structure as mutually co-constitutive and as dialectically intertwined: practices are conditioned - enabled, but also constrained - by structure (e.g. norms, understandings, positionalities, resources), and structure is being (re-)produced and changed over time through practices and action (GidDENs 1984; BORK-HüFFER et al. 2016).

Translocality denotes the connection of people and places through structures and practices across distances, linking both mobile (migrants) and non-mobile (families of migrants in their home location) populations (BRICKELL and DATTA 2011). It is along such translocal relations, grounded in imaginations and aspirations, attachments and notions of belonging, that translocal flows of people, finances, knowledge and goods are built and maintained. Livelihoods comprise the capabilities, the social and material resources, and the activities (practices and strategies) necessary for a means of living (CHAMBERs and ConwaY 1992). Translocal livelihoods are then, at least to a certain extent, relying on translocal exchange relations and practices. They are building on the mutual support of household parts at places of origin and destination in everyday life, and, through spatial and sectoral diversification, also in situations of crisis and localised resource shortfalls (SAKDAPOLRAK et al. 2016).

The concept of affordances in its original version (GIBSON 1979) refers to the properties of objects of offering possibilities for action: a table, for example, with its normal height, offers the possibility to humans of placing something on it. In communication studies, the concept was further developed and refers to properties of the relationship between 
humans and technology. These properties thus do neither result from inherent (technical or material) properties of technology, nor from the cultural construction of technology alone, but are emergent properties that arise from the interaction between technology and users (Hutchву 2001). As such, affordances are both the product of the application and usage of technology, and at the same time they condition its usage, and are thus a conditioning frame for how users perceive and use technology. A classic example in the field of mobile communication is the use of the backlit screen as a source of light, or that for poorer people mobile phones also represent a kind of investment, which can be sold in a situation of financial distress, in order to be able to make urgent expenditures.

In the context of this study, we draw upon SCHROCK's (2015) typology of communication affordances of mobile media, and on WELLMAN's (2001) differentiation of communicative situations (door-to-door, place-to-place, person-to-person) and distinguish three types of communicative affordances of mobile phones: first translocality and synchronicity, referring to the ability to communicate over distances and without temporal delay; although not unique to mobile phones, we include it with a focus on synchronicity here, because for most of the persons interviewed, the mobile phone was and is the first means of mediated communication. Second, individuality, denoting the ability to communicate from person-to-person, and with the possibility to identify the calling and the called person individually. Third, and most defining for mobile communication, portability, referring to the ability to carry the phone on the body and to communicate from any given place, and, linked through space-time-trajectories, also at any given time, even while mobile and moving.

From this perspective, humans do use mobile phones, because this allows them to overcome constraints that they are subject to. GIDDENs (1984) differentiates between three types of constraints: i) material constraints, related to the corporeal nature of the human body and its limitations for communicating over distance, through walls and to the fact that we are bound to certain time-space trajectories; ii) normative constraints, in the form of the social norms, rules and expectations that regulate and limit action and practices in everyday life, for example the engagement in romantic relationships; iii) structural constraints, for example the inequalities in resource allocation, power imbalances or the underlying structural reasons for labour migration, such as rural poverty and industrial labour available in urban centres.

\section{Research design and applied methods}

In order to reduce an analytical bias that could result from simply applying "Western" concepts to non-western lifeworlds, the analytical procedure combined inductive and phenomenological with deductive and more theory-driven research phases and approaches. The first phase consisted of a literature research on the topic of mediatisation and translocal livelihoods, a first exploratory field visit, observations, informal talks and expert consultations, and the establishment of the research design. In the second phase, 70 semi-structured interviews, two focus group discussions as well as observations were conducted with rural-to-urban migrants in Dhaka, and with rural dwellers in two selected villages in the Northern province of Rangpur, applying a multi-sited, translocal research design (MARCUS 1995). Interviews were conducted in Bangla language by the first author together with a translator. In the interviews, informants were, among others, asked to describe how they 
used mobile phones and what these meant for their lives as migrants and as families at the places of origin. Interviews were recorded, transcribed and translated into English.

In the third phase, we inductively derived a typology of mobile phone usage practices from the interviews. For the delineation of the types, we followed the logic of GoffMAN's (1986, p. 8) question characterising interactional situations: "[w]hat is it that's going on here?" Situations of mobile phone uses described in the interviews were thus clustered according to everyday interaction situations and contexts that are meaningful regarding the lifeworld of migrants and their rural household members. The typology was built up iteratively, adding new types until all interaction situations could be assigned to one of them and no new categories were necessary. This process involved close consultations with translators and experts in Bangladesh and resulted in eleven types of translocal mobile phone usage practices that are presented in the next section.

In the fourth phase, we analysed the interactional situations of these eleven types of practices with the framework of communicative affordances, constraints and translocal livelihoods. We thereby interpreted the mediatisation of translocal practices as a consequence of the way how migrants and their rural households draw on communicative affordances of mobile phones in order to overcome the various constraints that they face.

\section{Research sites}

Corresponding to the subject of the study, the research sites comprise both rural places of origin, as well as urban places of destination. For the rural sites, two villages in the District of Rangpur were selected. They are located approximately $300 \mathrm{~km}$ North of Dhaka, about $10 \mathrm{~km}$ East of the main road, corresponding to roughly 8-10 hours of travel time to Dhaka under normal traffic conditions. The distance from the villages to the nearest market town with some services and schools is about $2 \mathrm{~km}$ and $4 \mathrm{~km}$, respectively, and the distance to the nearest larger town, Pirganj, with governmental services, banks and high schools is about $5 \mathrm{~km}$. At the time of the field research one of the villages was connected to the electric grid, the other not; none of the interviewed households had access to tap water, but all relied on deep bore wells and filter systems instead. The most important livelihood source in the villages was small scale farming of paddy rice and vegetables, some cattle and chicken farming, and some small businesses (e.g. tea stalls). The majority of households surveyed were receiving remittances from migrants in urban areas or abroad.

In the region of Dhaka, migrants were visited at their places of residence and work, mostly informal settlements, in the Southwest and Northwest of the city, but also in industrial development areas northwest of Dhaka, in Savar and Ashulia. Most of the interviewed migrants were garment workers, rickshaw pullers, day labourers, construction workers, students and street food vendors.

\section{Types of mediatised translocal social practices}

The iterative process of coding and delineating categories of mobile phone usage practices yielded eleven types of practices. These encompass only those practices with at least a 


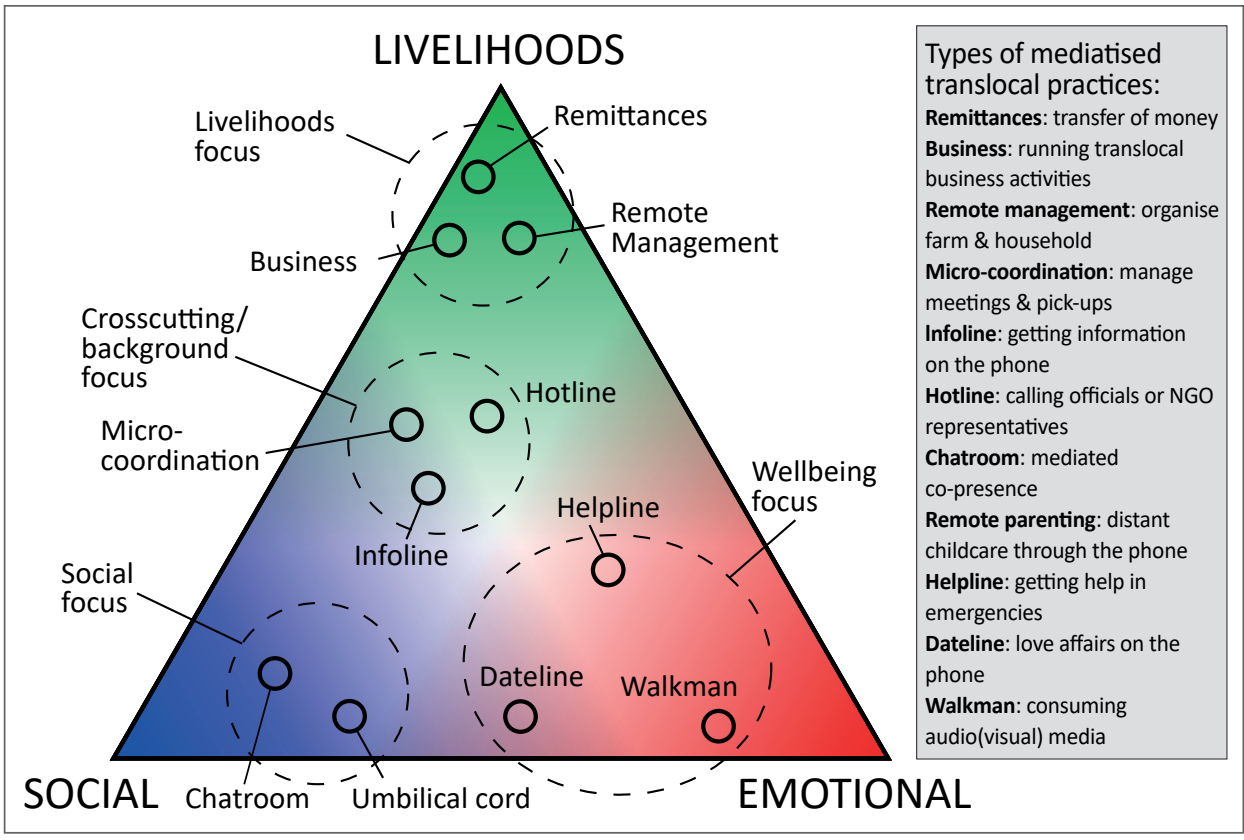

Source: Authors' own draft, based on interviews

Figure 1: Mediatised communication practices grouped and arranged along the three dimensions of livelihoods, social and emotional

certain degree of translocal character, i.e. involvement of people or places of rural origin and people or places in Dhaka. The degree to which this is the case is different: for the majority of categories, the translocal reference is explicit and strong, while others refer to both translocal as well as local (rural and/or urban) settings.

Putting these eleven types into the context of the everyday translocal lifeworlds of the interviewees, it is possible to group them into four broader categories (see also Figure 1): practices that are to a larger extent focused on sustaining or enhancing the translocal livelihood systems (remittances, business and remote management), practices that are mostly contributing to sustaining or managing social relations (chatroom, remote parenting, dateline - which is mixed here), practices that are geared mostly towards securing the individual or emotional wellbeing of the phone users (walkman, dateline, helpline), and practices that belong to a crosscutting or background informational category where specific or general information exchange is most relevant (micro-coordination, infoline, hotline).

\section{Remittances}

A central aspect of translocal connectedness in the Global South are the flows of financial remittances, which in Bangladesh as elsewhere form a significant part of migrant families' 
livelihoods. Mobile communication is linked to remitting practices - sending and receiving - in three ways:

First, mobile communication allows swift expression of the financial needs. While remittances are often sent in a regular manner, there are also occasions when a sudden need for financial resources arises, for example when a family member falls sick, or a climate hazard impacts the rural livelihoods. Through mobile phones this information can be timely communicated. In some cases, (especially seasonal) migrants use the mobile phone to ask for advance payments by their urban employers, in order be able to afford the journey back to the city. Batu, a rickshaw puller who was interviewed in the village during a holiday he spent there visiting his family, explains:

Batu: Suppose I need to go to back to Dhaka, and I need money for that. I ask: please send me 500 or 1,000 Taka.

Interviewer: You ask the [rickshaw] garage owner for it?

Batu: Yes, and he will send it. [...] He will send me 1.000 Taka and I have to pay him back doing the work.

(Batu, rickshaw puller, interview in Rangpur, 14.11.2011)

Second, mobile communication enables the organisation of transfers regarding amount, timing, or mode. Robi, a rickshaw puller from Dhaka, gives an example for this. He and his brother are living in different cities, and they both support their parents in the village:

Robi: One of my brothers stays in Cox's Bazar and has a flower shop. [...] I can talk with him [on the phone], and if I can't send enough money I tell him, brother, this month you send a bigger amount, and next month I will send extra, and you can send less then. If there would be no mobile phone, I had to inform him by letter - the letter goes, takes 12 days. After 12 days they will die in hunger.

(Robi, rickshaw puller from Dhaka, interview 22.03.2011)

Although Robi might exaggerate a bit at the end, he clearly explicates the difference in temporal delay between letters and mobile communication. Many of the persons interviewed stated that mobile communication enables them to effectively organise and monitor the financial transfers, be it through official or informal courier services, via friends or trusted persons travelling to the village:

Ratan: I call him [the possible courier] and ask him whether he will go home or not. If he goes home, I will meet him and send some money through him. I tell him to wait for me half an hour or one hour, then I am bringing the money. Then he takes my money.

(Ratan, rickshaw puller, interview in Dhaka, 24.03.2011)

Thirdly, migrants increasingly also use the mobile phone for directly transferring money. At the time of the interviews (2011-2013), only about half of the persons interviewed made use of mobile financial services (mobile banking) for remittances; this is likely to 
have dramatically increased - as those interviewed who did so, highlighted the convenience and safety of the procedure, and as the system was comparably new in 2013, having just started in 2011. The number of agents who do the actual cash-in and cash-out transactions has risen from about 80,000 in 2013 to 980,000 in 2020, and the number of registered clients has jumped from about 400,000 to 80 Million in the same time (Bangladesh Bank 2020).

\section{Business}

Some of the interviewed persons had own non-agriculture businesses (mostly trading, rickshaw garages), and most of them practiced small scale agriculture. Those in non-agricultural businesses emphasised the importance of the mobile phone for improving access to and reducing the cost of getting relevant information (e.g. prices), organising the procurement of goods, keeping contact to customers or organising assistance in problematic situations. For those involved in agriculture, the mobile phone provides access to market and price information, but also allows a once-established business at the place of origin to be remotely managed when being in Dhaka (see also chapter 4.3 Remote Management). One interview partner had started a lucrative business involving the trade of cattle fodder (straw) from his rural home to Dhaka during the time of Eid-ul-Azha, when hundreds of thousands of cows are brought to the city for ritual slaughter but have to be fed the days before the event. The cattle fodder business is based on kinship and friendship networks and to a large extent managed and organised through mobile communication.

Rezwan: I observed that cows were searching for straw, then I went to buy straw. Then the straw which cost 2 Taka in our village [...] but I have to buy that [in Dhaka] for 15 Taka!

Interviewer: Brother! Its too high.

Rezwan: Then I thought that [...] as I have people in the village [...] I can try by calling through the mobile phone [...] I couldn't let Jamal sleep [called him in the night] [...] asked him to bring a truck load of straw [from the village to Dhaka] at any cost. Interviewer: So, you were in Dhaka then?

Rezwan: Huh, I was in Dhaka [...] I called him on the phone at $12 \mathrm{am}, 1 \mathrm{am}, 3 \mathrm{am}$, I mean the full night I talked with him through the phone [...] I told him to bring 10,000 [bunches of] straw, and a sack of molasses.

(Rezwan, rickshaw puller in Dhaka, interview in Madarganj, 13.11.2011)

Also, the vending business needed to be carefully organised, as places along the streets are already occupied and there are informal or semi-illegal networks and hierarchies of influential people and gangs that control the informal economic activities. The interviewee - as an "ordinary" rickshaw puller - managed to organise and secure a sales place for his cattle fodder, through communication with important people on the phone:

Rezwan: Then (laugh) [...] when I call [...] they [goons] told me [...] brother listen, I'll not ask you again [...] forgive me for this time. 
Interviewer: That means there was a problem there [...] I mean goons [...] Rezwan: They came [...] when they came [...] I have Babu bhai's [an influential personality] phone number [...] I told them to talk to Babu bhai through the phone [...] Then they said I'll give you everything for your straw selling.

(Rezwan [Nayon], rickshaw puller in Dhaka, interview in Madarganj, 13.11.2011)

\section{Remote management}

Both homesteads and family affairs, but also small-scale farming in the village need constant maintenance and management. Although the daily management of the distant (rural) homestead is often left with close relatives (e.g. parents, the spouse, siblings) during the absence of migrants, many of the interviewed migrants engage in important decision-making (e.g. financial issues, commissioning of works, family celebrations). These are discussed on the mobile phone, which enables both control and joint decision making on running affairs, as the cases of Abdul and Forid shows:

Abdul: We [...] have land, and it is time for cultivating the land. [...] there is the need to sow, this is needed to be done, OK?

Interviewer: $O k, o k$.

Abdul: We need to buy medicine and fertilizers. About these [things we talk]

(Abdul, garment worker in Dhaka, interview 01.11.2011)

Forid: [In the village] I have goats, I have chicken and ducks, what is their condition? I ask about those. These chicken are my big hobby. Suppose I bought one chick only. Now there are ten to fifteen. Selling some, and the others are laying eggs, then again selling, again laying eggs.

(Forid, Factory Worker in Dhaka, Interview 09.03.2013)

\section{Micro-coordination}

Micro-coordination refers to the organisation and temporal and spatial synchronisation of activities and mobilities "on the fly" (LING 2004, p. 18), for example readjusting and renegotiating meetings and joint activities. This is especially relevant in Dhaka where traffic conditions often do not allow for reliable "clock-time" (LARSEN et al. 2008) based synchronisation with others, but also in rural areas:

Munsar: I phone the person who has a mobile and tell them "Come to this place at this time, I will meet you."

Interviewer: Do you fix such meeting by any other medium?

Munsar: It is possible but it's a kind of harassment, it causes harassment. And if you have a mobile phone, now everyone has a mobile phone, if you know the number, you just call and that's all. They will come.

(Munsar, vegetable trader, Rangpur village, interview 08.03.2013) 
The ability to flexibly arrange and rearrange face-to-face-meetings and keep contact through mobile calls was mentioned also as helpful for establishing local social networks, for example after the initial arrival in Dhaka.

But the ability to communicate over distance and "en route" also enables actors to organise and thus facilitate mobility - both migrating and visiting - between the rural and the urban, for example arranging to be picked up by family members at the bus stop when visiting relatives:

\section{Infoline}

"Infoline" stands for the practice to quickly and easily access and acquire information on a variety of topics. For most of the persons interviewed, the opportunity of receiving or sending real-time information about their wellbeing or that of their family members at distant locations was among the most important uses of mobile phones. Especially the health status of elderly parents living in distant places was frequently a major subject of concern, but also the educational progress of children living in the village. Access to information is also important for getting jobs as day labourers, both in rural areas as well as in Dhaka, thus in some cases also triggering (temporary) migration. Other fields of concern are for example police controls, traffic conditions or information about public security during strike days.

Interviewer: Suppose, during a natural disaster, for example when floods or strong wind destroy houses, how would the mobile phone be of any use during such?

Munsar: Yes, it's of great use. Suppose, there is a strong wind or like this, we can ask our relatives: "how is the wind, rain or hailstorm there [in the village]?"

Ahmad ( $2^{\text {nd }}$ person present): The information can be taken.

Ahmad: It can be done very easily. It [the mobile phone] is useful.

Munsar, vegetable trader, Rangpur village, interview 08.03.2013

\section{Hotline}

"Hotline" captures the ability of actors to contact officials or representatives of official bodies - governmental or non-governmental organisations and corporations, doctors, political leaders. This refers to both local and translocal settings; many interview partners valued that they can substantially save on time and (local) transportation cost when contacting for example the agricultural extension service by calling, or for getting in touch with NGO representatives regarding a micro-credit. Medical services are increasingly available through government or NGO related call centres, but, in the case of rural areas, also in the form of local doctors who can be called in emergency situations and who will then visit the patient. Local political leaders (usually influential party cadres) play an important role in both urban and rural areas and can easily be reached by phone when needed:

Interviewer: Now let us think about some powerful persons: political leaders, landlords and the like. How important is the mobile phone in keeping communication with them? 
Tahmina: Very important. You can communicate with the clerks at Pirganj [larger town approx. $5 \mathrm{~km}$ from the village] sitting here. If I buy or sell land, [I can enquire] when I should go, what's the value, etc., I can know, and [also when] I need to manage the money. These are the advantages. I don't need to go there every day by cycle or van. I can do everything over phone. Whether selling land or house or buying, what's the value, how much money is needed, I can hear everything sitting here.

(Tahmina, farmer and NGO worker, Rangpur, Interview 08.03.2013)

The chairman of the rural Union (administrative unit) explains:

For example, if there is a trouble in the village, [they call me and say] "Chairman please come here." Then I have to go. Then there is a need of birth certificate: "Chairman, where are you?" I say, "I am at home." [They say:] "I have gone to Pirganj, please bring the seal with you, I need the birth certificate tomorrow, I am already on my way to Dhaka." [...] [I say:] "So wait there, I am on the way." That means the people now don't want to wait. And earlier they would come to me five days [in advance] for [solving] a problem. Now they want the problem solved by me while they are staying at home.

(Interview with the Union Chairman, Madarganj in Rangpur, 10.03.2013)

In the last sentence, the Chairman highlights an ambivalent aspect of mobile communication: the improved access for the villagers also means more stress for him due to permanent availability.

This type of practice also happens translocally, between the rural area and Dhaka, showing the importance of the linkages that migrants keep with their rural origin:

Suppose, a few days ago, one police officer called me from Dhaka, and he asked: "How are the characters of these two men of your area? We arrested them under suspicion." Then I found their characters are good. Then I informed him [the police officer] and he took the necessary steps and released them. These are the facilities [of the mobile phone]. It was impossible without mobile phone.

(Interview with the Union Chairman, Madarganj, in Rangpur, 12.11.2011)

\section{Chatroom (ādd $\bar{a})$}

"Chatroom" refers to communicative situations where the experiencing of co-presence, shared time and attention is in the foreground, and where the exchange of factual information is less important than hearing the voice of and being near to others. This takes place most often between two closely related individuals, for example spouses, children and parents, siblings, or among friends, but can also comprise a group, as Anwar, rickshaw puller in Dhaka explains. He frequently chats with a group of friends in the village:

Anwar: Going out I get 20 Taka balance in mobile and talk with friends [in the village]. They are sitting down there, switching on the loudspeaker, 4 to 5 people listen 
to me and have fun.

(Interview with Anwar, rickshaw puller in Dhaka, 22.03.2011)

In the Bangla traditional culture, this kind of popular informal group conversation, often accompanied with tea and snacks, would be referred to as ạḍ̂a, or informal chat, hence the title. These conversations often take place at locations that offer some degree of privacy or quietness, which is especially relevant in the high-density context of Dhaka, or while walking and on the way, which is often the case in the village. For the majority of the persons interviewed, the mobile phone opens the opportunity for frequent, often daily interaction with relatives; it is such frequent and intimate contact that helps to keep relationships over the distance intact and alive:

Interviewer: Okay, when they are communicating on the phone, does this damage the relationship?

Forid: No, no.

Interviewer: Because, look, if you visit personally and speak, it creates love and affection.

Forid: No, if you speak through mobile, it also creates love. It does not destroy the attachment.

Interviewer: Okay the attachment is the same if you visit personally or speak through mobile?

Forid: Yes, if you speak through the mobile, it stays the same.

(Forid, factory worker in Dhaka, Interview 09.03.2013)

Although this form of colloquial chatting might at first not seem to be as important as "functional" interactions (such as financial transfers, organisation of affairs, etc.), interview partners expressed that they are vital for sustaining relations of mutual trust and reliability, and a sense of proximity. Shared time and attention and empathy of close relatives also contribute to psychological wellbeing and resilience of migrants and non-migrants:

Rahim: When they call over phone, it seems that they are just near.

Interviewer: $O k$

Rahim: Then we feel happy.

Interviewer: Ok, if there were no mobile, then how would it be?

Rahim: It would be a kind of suffering. We can't know or inform what goes on there or here. If they do not call for 2 or 1 days, our hearts become restless: how are they or what is their situation.

(Rahim, vegetable trader, living in Rangpur, two children in Dhaka)

\section{Remote parenting}

"Remote parenting" refers to remote caregiving and parenting to children, when their parents are absent from the village and the children remain in the village. Analogous to the practice that in the literature is described mostly for international migrants from the Phil- 
ippines ("remote mothering") and in the Chinese examples for domestic migration, this exists also in Bangladesh. The need for "remote parenting" arises from the lack of day care facilities in Dhaka, as the living costs in the city and the expectations for remitting money to the village often require both parents to engage in formal or informal employment or businesses. Usually such children would then be under the custody of grandparents or other close relatives in the village. Sometimes parents also send their children home to the village once they reach schooling age. Although among the interviewees in Dhaka only a minority had their children in the village, for those who had so, the ability to communicate on a regular, often daily basis with their children as well as to discuss educational matters was of great importance. While mothers play a much stronger role in remote parenting than fathers, there were also fathers among our interview partners who reported on caring for their children through the phone.

Sayeda is a garment worker and lives with her husband in Dhaka. Her two daughters aged seven and nine live with their grandmother in the village, and Sayeda calls them every day. She explains how the mobile phone helps her to enact - and keep - her parental authority over her daughters:

Like in this noon, [I called and asked] what they are doing, I can stay in touch with them, I can talk with them, and they will listen. Even if I say it [only] over mobile they will listen. So, that will be good. [...] If I myself [...] tell them to eat and sleep, then they listen. [...] [But they] don't sleep properly, if anyone else is telling [them] to sleep or to eat [...]

(Interview with Sayeda, garment worker in Dhaka, 14.12.2011)

\section{Helpline}

"Helpline" - in contrast to "hotline" - represents the contact to rather non-official people, mostly members of the personal network in situations that are characterised by urgency or emergency, for example in situations of need for advice, financial, health, emotional or other forms of support. This refers for example to calling relatives when affected by natural hazards (storm, floods) or when medical help is needed:

Interviewer: Now, let's talk about some crisis events. For example, in the moments of sickness or during any natural disaster, how can the mobile be used in such cases? Tahmina: [...] Suppose, the wind blew and broke the house. But the grandfather is not at home. Then we can call him and say, "Come, the house is broken into pieces by the wind." [...] Then suppose, if we have a patient at home who is very serious, and we need a doctor. [...] If I have the phone number of a doctor, I can call him over phone, "Please come, my patient is very serious." Then it is very helpful.

(Tahmina, farmer and NGO worker, Rangpur, Interview 08.03.2013)

Many of those persons interviewed, especially, but not only the migrants, recall events when they had been victims of psychological or physical violence (e.g. becoming tricked, 
mugged, insulted, etc.) and benefited of the ability to immediately mobilise support from friends or relatives. For migrant workers, especially the psychological support from close relatives in the village is important.

Alam, a rickshaw puller, gives an account how the police confiscated his rickshaw because he did not have a valid registration plate; often the police then takes advantage of the situation and demands bribes from the rickshaw-pullers to release the vehicle. However, Alam could use the mobile phone to leverage the support of his employer:

Interviewer: What happened there?

Alam: [...] There was a problem with the plate number [...] This vehicle number was valid for Mirpur [...] But that area, Farmgate, is under Dhaka City, [so...] I can't go there, that's why police took my vehicle.

Interviewer: Oh, what happened next?

Alam: Then I called the owner, the manager [of the rickshaw garage/business]. Manager came there [...] and gave them 500 Taka and resolved the incident then.

(Interview with Alam, rickshaw-puller, Dhaka, 06.11.2011)

\section{Dateline}

"Dateline" refers to the calling of other numbers and the attempt to enter a romantic relationship (and / or sustaining such a relationship), in media and popular culture in Bangladesh commonly labelled as "mobile romancing" (STERLY and GERADS 2016). Phone numbers of potential contacts are sometimes randomly dialled, sometimes the numbers are exchanged among friends or illegally acquired from prepaid balance vendors. In many cases this is a form of and perceived as harassment especially by women, and we want to emphasise here that the term (and the associated framing) of "mobile romancing", although used by both men as well as women in the interviews, stems from and represents a strongly male-dominated sociocultural reference-system. The "dateline" practice is often inherently translocal, when the dialling of random numbers connects people across longer distances, sometimes also linking migrants with their specific places of origin.

Robi, a rickshaw puller in Dhaka, explains how he got called by a woman unknown to him:

Suppose yesterday [I got a call] in my aktel [a mobile service provider] number. Suddenly a girl, a missed call came. I called her back again. I had 5 Taka [balance] in my mobile, I finished that. I asked: "Where did you get my mobile number?" "No brother, I dialled the wrong number" [, she said]. I said: "Which number, because dialling any number generally [means that the] call goes in a wrong number." She said: "Because of one digit." I asked: "Which number, please give me that number, and I will check, is it really the wrong number or you just willingly dialled the wrong number." [...] She then said that she willingly dialled the number [...] and if [I] like [she] will talk [to me].

(Robi, rickshaw puller in Dhaka, interview, 22.03.2011) 
Under the label of "mobile romancing", this is also a matter of public and media discourse, and a popular topos is the development of these initially illegitimate and often unwanted relations into truly romantic relationships and even marriages:

If they fall in love, whether the boy falls in love or the girl falls in love, then they must meet one another, at some point they must meet. Doesn't it happen? Yes, in most of the cases it happens. Besides, sometimes they do this just for fun. Okay, they're having fun living at a distant place. Such things happen.

(Interview with Din Islam, rickshaw puller, Dhaka, 24.03.2011)

We are aware that from an ethical viewpoint it is difficult to fit these different outcomes harassment and romantic relationship - into one category. But even if women are the minority in actively engaging in this practice, calling (random) others in order to engage in new relationships, they nevertheless also do so. In our view this shows how both men and women very strategically draw upon technological affordances to overcome strong normative constraints regulating ("romantic") relations between members of opposite gender.

\section{Walkman}

"Walkman" pertains to the use of mobile handsets for audio (and also audio-visual) entertainment - listening to music, watching pictures and videos. As multi-media handsets become more affordable (used ones from approx. 20 EUR), they are owned frequently also by members of lower income groups. Especially rickshaw-pullers in Dhaka reported to make frequent use of their phones for listening to music or to watch movies, sometimes to kill time while waiting for customers or for relaxation, but also in the villages, media consumption was frequently mentioned. Media files are exchanged via Bluetooth, on memory cards, or are acquired from mobile phone vendors:

Interviewer: Well, those who buy memory or mobile sets from here, how many of them do also load songs or other things from you?

Kasim: That is done by 90 percent of people.

Interviewer: That means almost all do that.

Respondent: Yes, maximum people do that.

(Interview with Kasim, mobile shop owner, Madarganj, 31.11.2011)

"Walkman" also includes more explicitly translocal practices of distant media sharing, as it significantly contributes to the spatial diffusion of audio-visual media. This takes places both from urban to rural areas and households, but also from rural to urban, in form of the consumption of pictures and video recordings from rural areas by migrants in Dhaka. This contributes to a translocal flow and exchange of media, imaginaries, styles and preferences. However, due to the high costs of internet data packages and the comparably low prevalence of smartphones at the time of the research, the immediate sending of such audio and visual media was very uncommon and was rather happening through bringing along during visits. 


\section{Mediatisation as overcoming constraints by drawing on media affordances}

To elucidate what drives these usages of mobile phones in translocal constellations and practices, we trace how mobile phone users draw on the affordances (synchronicity/ translocality, individuality, portability) of mobile communication to overcome specific constraints (material/corporeal, normative, structural) that limit their scope of practice and agency. We thus "map" the eleven mediatised practice types (see chapter 4 and Figure 1) against the different affordances and constraints by asking: a) how necessary the different affordances are for carrying out the respective practice types; and b) in how far these affordances do allow actors to overcome the different constraints for interaction.

The importance of the affordances is assessed by asking how well each practice type could be realised with alternative forms of mediatised communication that do not present the respective affordances: The importance of synchronicity is assessed with the question how well the practices could be realised with postal letters (as the latter afford translocal, but not synchronous interaction), the role of individuality is analysed with the question in how far a call shop or a shared device would allow the practices to be carried out (as they afford synchronous, but not individualised interaction), and the role of portability is assessed with the question whether access to a individually owned landline phone would enable actors to perform the respective practices (as it affords individualised, but not mobile interaction).

Regarding the constraints, for each practice type it is asked whether or in how far the employment of the mobile phone in the respective practice does help to do or achieve something that is constrained by the physical distance, or the limitations of the human body (material/corporeal), that otherwise would be difficult to do because of social expectations, rules or norms (normative), or that would be difficult due to unequal access to resources, power and decision making processes (structural constraints).

Table 1 shows the results of this "mapping". To give an example: most of the hotline type practices (contacting officials, doctors, etc.) necessitate synchronous communication, as postal letter exchange could not replace the phone due to the time delay (hence ' ++ '); the individuality of an individual phone would in many cases be helpful ('+') but not necessary, as a shared phone or a call centre still would allow the practices to be performed; the portability of the mobile phone is not a necessary condition, a personalised landline phone would be sufficient. Regarding the constraint side, the practices of the hotline type help to overcome material-corporeal constraints, bridging short as well as long distances in all cases ('++'); they overcome normative constraints in many cases, making it easier for marginalised people to contact powerful and influential persons ('+'); and they overcome structural constraints, improving the access to resources and decision making processes in many cases ('+').

\section{Affordances}

It becomes clear that mobile phones play different roles for the respective translocal practices: The affordance of translocality, i.e. communicating, exchanging information, estab- 


\begin{tabular}{|c|c|c|c|c|c|c|}
\hline \multirow[b]{2}{*}{ Practices } & \multicolumn{3}{|c|}{ Affordances } & \multicolumn{3}{|c|}{ Constaints } \\
\hline & $\begin{array}{c}\text { translocality } \\
\text { and } \\
\text { synchronicity }\end{array}$ & individuality & portability & $\begin{array}{l}\text { material- } \\
\text { corporeal }\end{array}$ & normative & structural \\
\hline Dateline & ++ & ++ & ++ & ++ & ++ & $(+)$ \\
\hline Micro-coordination & ++ & ++ & ++ & ++ & & + \\
\hline Helpline & ++ & ++ & ++ & ++ & & $(+)$ \\
\hline Chatroom & ++ & ++ & ++ & ++ & & \\
\hline Hotline & ++ & + & & ++ & + & + \\
\hline Business & ++ & + & + & ++ & & + \\
\hline Remote parenting & ++ & + & & ++ & + & \\
\hline Infoline & ++ & + & & ++ & & + \\
\hline Walkman & + & ++ & + & + & + & \\
\hline Remittances & + & + & & ++ & & + \\
\hline Remote management & + & + & & ++ & & $(+)$ \\
\hline
\end{tabular}

Affordances: ' ++ ' $=$ necessary, ' + ' $=$ helpful. - Constraints: ' ++ ' $=$ in all cases, ' + ' $=$ in many cases, ' $(+)$ ' $=$ in some cases.

Source: Authors' own draft, based on interview data

Table 1: Mapping mobile communication practices against affordances and constraints (sorted by number of affordances and constraints concerned)

lishing proximity, or organising things over distances, is essential for all of these practices, while individuality and portability are only important for some of the practices. The latter would not be possible at all without mobile phones, such as dateline, micro-coordination, helpline and chatroom, because for them, the affordances of portability and individuality are necessary prerequisites. This means that the defining affordance of the mobile phone, it's portability, is not invoked for so many of these practices: The practices for which individuality and portability play a less important role can also be realised without mobile phones. For example, information exchange (infoline, hotline), remote management of households and farms or the care of children (remote parenting) are also possible from mobile call shops, and remittances would be and are also transferred without mobile phone involvement.

The mobile phone with its specific affordances (portability and individuality) is therefore not necessarily the central element that makes all these practices possible, but rather the possibility of communicating synchronously over distances. However, since most of the interviewees - poorer rural-urban migrants - had no access to telephony at all before the massive spread of mobile phones and were dependent on visits or letters for communication over distance, the mobile phone took over the "role" that in other contexts landline phones, call centres etc. would have. What specific affordances actors draw upon depends on factors on individual and on social level, for example their position, their gender, or their personal aspirations. On a higher level, for example the accessibility of infrastructures and technologies such as fixed-line telephones condition whether the mobile phone 
only offers additional portability or whether all its affordances are relevant. This makes it clear that mobile phones and mobile communication do not affect societies uniformly, but that local peculiarities or idiosyncrasies are decisive on how these technologies are used and what effects on society arise from the technology usage.

\section{Constraints}

Material and spatial constraints (distance), normative constraints (rules and expectations, gender norms etc.), and structural constraints (poverty, power relations) regulate and limit local and especially translocal practices and agency to a considerable extent. Physical distance, for example, is an obstacle to almost all translocal practices; norms restrict the way how intimacy is practised, and poverty and power imbalances constrain regular visits by migrants to their places of origin. It is primarily the material distance and physical constraints that are overcome here; this is less often the case for normative or structural constraints.

Which constraints are overcome with mobile phones is partly related to the affordances drawn upon: while synchronicity and translocality are key to overcoming the material and corporeal constraint of distance, portability and individuality can also enable actors to overcome normative and / or structural constraints. This becomes most obvious for the case of the dateline practice: actors draw on the individuality and portability afforded by mobile phones in order to overcome normative constraints, i.e. the (restrictive) norms and rules that regulate premarital and extramarital partnerships in the Bangladeshi society.

Both normative and structural constraints are overcome only to a limited extent: the business or hotline practices would be examples where the mobile phone sometimes opens up opportunities that migrants or poorer sections of the population would otherwise not have, through the access to information, to gate-keepers or to decision-making resources. However, in general, the mobile phone seems to be only of little help to perform practices or agency, or achieve things, that are constrained by strict normative rules or by an unequal distribution of material and power resources. This means that mobile communication (technology) as such is not a "silver bullet" to overcome inequality and discrimination.

\section{Contextualising mediatised practices in translocal livelihoods}

In order to contextualise the mediatised practice types, we systematised them according to their role within the overall translocal livelihoods context. In a first step, we have thus ranked the eleven practice types (see chapter 4) according to their importance for the translocal livelihoods of migrants and their rural household members. Then we combined this information with the previous insights into the role of mobile communication for these practices, by scoring them by the number of affordances drawn upon and the constraints overcome. When allocated in a synoptic $\mathrm{x} / \mathrm{y}$-diagram, the rank and score help to get an impression of the logic of action of the actors and what role the mobile phone plays in this. Figure 2 shows the diagram with the two axes: $x$ is the importance of the eleven translocal practice types, and $\mathrm{y}$ is the role of mobile communication for these eleven practices. 


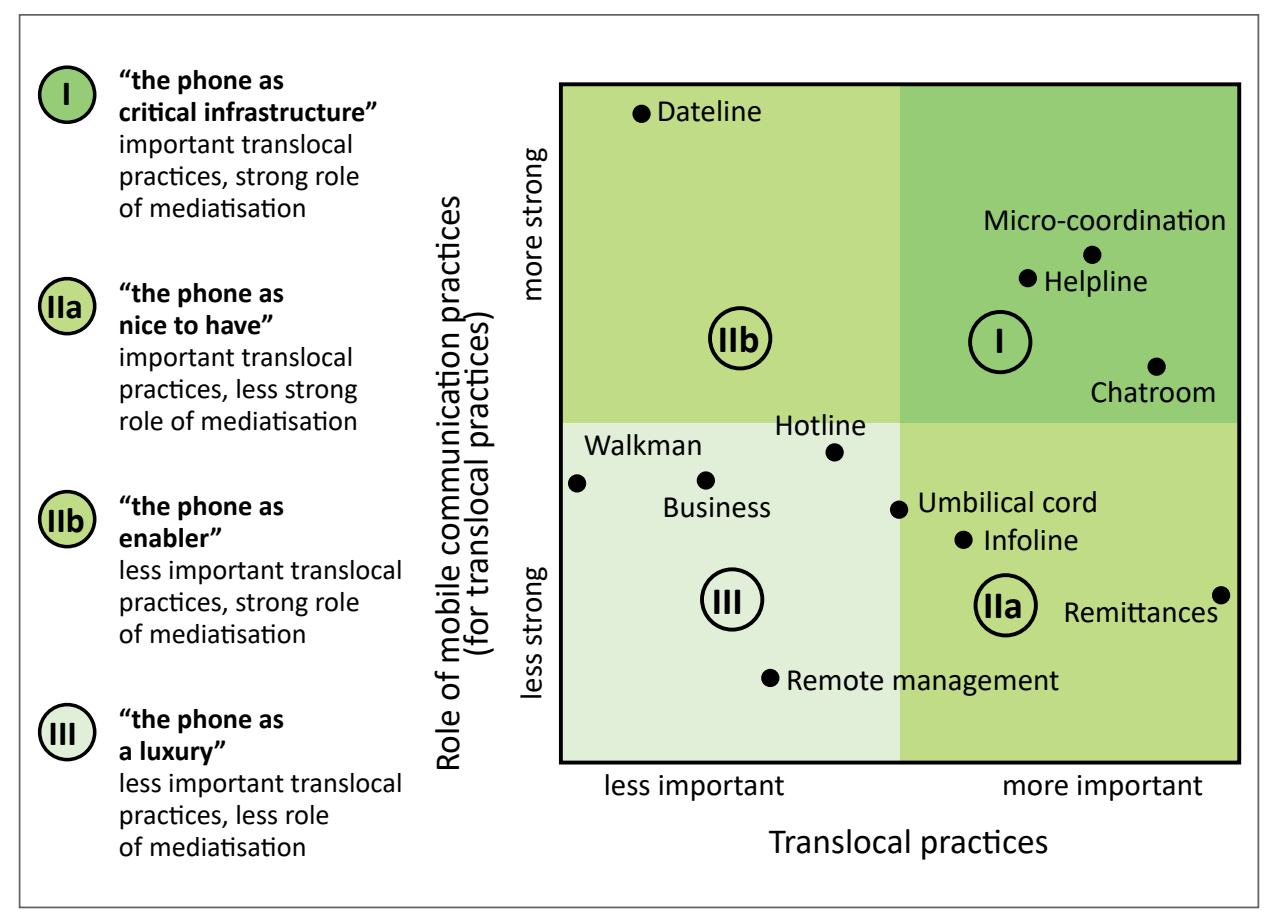

Source: Authors' own draft, based on interview data

Figure 2: Fields of relevance of mediatised translocal practices

In an idealised form, the following four meta-types of mediatisation can be abstracted:

I - the mobile phone as "critical infrastructure" (referring to the term for essential infrastructure for national security): These practices are important for translocal livelihoods, and the mobile phone is essential to carry out these practices (in their described form); this includes micro-coordination, chatroom and helpline.

IIa - the mobile phone as an "extension": Practices are important for translocal livelihoods, but the mobile phone does not play such a central role; this includes remote parenting, infoline and remittances.

$\mathrm{IIb}$ - the mobile phone as "enabler": Mobile communication is central, but the practices are not so important regarding the overall translocal living, this comprises dateline.

III - the mobile phone as a "supplement": practices are not so relevant within the overall translocal livelihood context, and the mobile phone does not play a central role; this includes the hotline, business, remote management and walkman practices.

Two points become clear from the above:

First, and generally, the mobile phone, or the mediatisation of translocal communication enhances the scope for translocal practices and agency. It does so through expanding 
the capabilities of actors to act in time and space, and to some degree also to overcome or subvert normative and also structural constraints. This is also reflected by the generally positive appraisal of mobile communication by most interviewees.

Second, however, this needs to be differentiated by types of practices and also by actor(group)s to avoid conflation: Mobile communication is not equally important and equally enabling for everyone. For certain actors and the practices that are meaningful to them, certain features and affordances of the mobile phone are more important than for others: Some actors for example do not have a business, thus for them, the mobile phone is less useful / operational for overcoming the respective structural constraints than for others; for those who engage in the dateline practices, portability and individuality are indispensable for overcoming or subverting normative constraints.

While this paper's focus is on translocal practices and not on structural change, it needs at least to be noted that the mediatisation of translocal social practices of course also influences the spatial and temporal organisation of the translocal social constellations of migrants and their rural "counterparts": Most notably, mediatisation leads to a "quotidianisation" of previously rather episodic translocal practices and thus "brings back" the translocal into everyday life.

This is accompanied by a repositioning of position-practice relationships - interactions and transactions are literally "taking place" in other and new locations. Both together can be summarised under a "re-regionalisation", a spatial and temporal re-ordering of translocal practices. And there are also changes of positionalities, relations and places, very obvious for example in the spatial and organisational restructuring of the ways how remittances are being sent. Such changes also entail transformations in the structures concerning communication itself, for example shifting norms and expectations regarding the frequency of communication and remittance sending, the increase in organisational and physical infrastructure in the form of mobile phone shops and base-towers, or the effects on social inequalities by creating new information "have" and "have-nots" (cf. LING 1998).

The predominantly positive assessment of mobile phones for the practice types and the livelihood contexts does not reflect our personal judgement but reflects most of the statements made by interviewees. We interpret this largely positive perception also as a consequence of the limited access of the interviewees to other communication media than the mobile phone.

\section{Conclusion}

Information and communication technologies in general, and mobile phones in particular are gaining more and more importance for the lives and livelihoods of people around the world - including poorer sections of the society in the Global South. While there has been extensive research on various aspects of ICT in the context of international migration particularly South-North migration - less attention has been paid to ICT and domestic migration in the Global South. Based on multi-sited empirical research on rural-to-urban 
migration in Bangladesh, the paper narrows this gap by describing the range of types of mediatised translocal practices and by explaining the reasons and importance of the use of mobile phones.

A practice perspective on the mediatisation of translocal lives, and specifically a focus on the importance of the mobile phone for people to overcome constraints, and how phone usage practices are embedded in the translocal realities and livelihoods helps to better understand why also poor people sometimes use considerable parts of their income for calling: It becomes clear that this "calling" has very different functions and meanings, and that people consciously spend income for affordances that the phone offers to them. These can be very specific, according to their situational needs and expectations, and to what they value - privacy for example is of different importance for people in a distant romance than it is for others.

What HutchBy (2001) calls, in an abstract way, the human-technology interaction, can be observed very concretely here: From the interaction of existing practices, actors' aspirations, their specific constraints and their perceptions of the usability of mobile phones, certain affordances arise, which are then becoming relevant in the particular context.

Finally, while it could be shown that the affordances provided by mobile phones enhance people's scope for agency to overcome material and corporeal constraints, normative and structural constraints are less often challenged. From that, it can be deduced that mobile communication should not be expected to have a strong effect on changing social norms and larger structures of unequal access to resources and power that affect rural-to-urban migrants and their households at places of origin. Mobile communication per se does not contribute to the reduction of inequality, to the improvement of political participation, or to more gender justice. As Ahmad, a teacher in the village, puts it:

Now, with this, everyone will get benefit according to their mode of communication. Those who are highly educated, they are using it for many purposes like office etc. Those who are businessmen they are using it for business purpose. Those who belong to lower class, they use it for talking to their friends and relatives.

(Interview with Ahmad, college lecturer, Rangpur village, 08.03.2013).

To put these findings further into perspective, it needs to be said that these mobile phone usage practices are not specific for, or only observed among migrants, but also in other population groups. But the mediatisation of translocal practices is especially relevant for the lives and livelihoods of migrants and their families, which is reflected in the largely positive judgement of mobile communication by the interviewees. It needs however also to be seen in conjunction with other ongoing (and previous) transformations, for example the expansion of road and railroad infrastructure and of affordable transportation modes.

There are a number of open questions and promising research fields regarding the topic, for example the effects of more recent digital media (e.g. smartphones) on social and translocal practices, and on new inequalities and "digital gaps". More research in the science-practice interface is also needed on the mechanisms and potential pathways for realising the full potential of mediatised (translocal) practices for social change. 


\section{References}

Ahlin T. (2020): Frequent Callers. "Good Care" with ICTs in Indian Transnational Families. In: Medical Anthropology, 39 (1), pp. 69-82. - https://doi.org/10.1080/01459740.2018.1532424.

Alampay E. A., Moshi G. C. (2018): Impact of Mobile Financial Services in Low- and Lower-Middle-Income Countries. A Systematic Review. In: Information Technologies \& International Development, 14, pp. 164-181.

Aricat R. G., Karnowski V., Chib A. (2015): Mobile Phone Appropriation and Migrant Acculturation. A Case Study of an Indian Community in Singapore. In: International Journal of Communication, 9, pp. 2221-2242.

Bangladesh Bank (2020): Mobile Financial Services (MFS) Comparative Summary. - https://www. bb.org.bd/fnansys/paymentsys/mfsdata.php (last access: May 2020).

Barber P. G. (2008): Cell Phones, Complicity, and Class Politics in the Philippine Labor Diaspora. In: Focaal, 51, pp. 28-42. - https://doi.org/10.3167/fcl.2008.510104.

BBS - Bangladesh Bureau of Statistics (2015): Population and Housing Census 2011 Database. http://www.bbs.gov.bd/site/page/47856ad0-7elc-4aab-bd78-892733bc06eb.

BoAs I. (2020): Social Networking in a Digital and Mobile World. The Case of Environmentally-related Migration in Bangladesh. In: Journal of Ethnic and Migration Studies, 46 (7), pp. 1330-1347. - https://doi.org/10.1080/1369183X.2019.1605891.

Bork-Hüffer T., Etzold B., Gransow B., Tomba L., Sterly H., Suda K., Kraas F., Flock R. (2016): Agency and the Making of Transient Urban Spaces. Examples of Migrants in the City in the Pearl River Delta, China, and Dhaka, Bangladesh. In: Population, Space and Place, 22 (2), pp. 128-145. - https://doi.org/10.1002/psp.1890.

Brickell K., Datta A. (eds.) (2011): Translocal Geographies. Spaces, Places, Connections. Farnham: Ashgate.

Cabanes J. V. A., Acedera K. A. F. (2012): Of Mobile Phones and Mother-fathers. Calls, Text Messages, and Conjugal Power Relations in Mother-away Filipino Families. In: New Media \& Society, 14 (6), pp. 916-930. - https://doi.org/10.1177/1461444811435397.

Chambers, R., Conway, G. (1992): Sustainable Rural Livelihoods: Practical Concepts for the $21^{\text {st }}$ Century. Sussex: Institute of Development Studies (= IDS Discussion Paper, 296). - http:// opendocs.ids.ac.uk/opendocs/bitstream/handle/123456789/775/Dp296.pdf?sequence $=1$ (last access: May 2020).

Chib A., Malik S., Aricat R. G., Kadir S. Z. (2014): Migrant Mothering and Mobile Phones. Negotiations of Transnational Identity. In: Mobile Media \& Communication, 2 (1), pp. 73-93. - https://doi.org/10.1177/2050157913506007.

Costa E. (2018): Affordances-in-practice: An Ethnographic Critique of Social Media Logic and Context Collapse. In: New Media \& Society, 20 (10), pp. 3641-3656. - https://doi.org/ 10.1177/1461444818756290.

Couldry N., Hepp A. (2013): Conceptualizing Mediatization. Contexts, Traditions, Arguments. In: Communication Theory, 23 (3), pp. 191-202. - https://doi.org/10.1111/comt.12019.

Cuban S. (2014): Transnational Families, ICTs and Mobile Learning. In: International Journal of Lifelong Education, 33 (6), pp. 737-754. - https://doi.org/10.1080/02601370.2014.963182.

de Bruijn M., Nyamnjoh F., Angwafo T. (2010): Mobile Interconnections. Reinterpreting Distance, Relating and Difference in the Cameroonian Grassfields. In: Journal of African Media Studies, 2 (3), pp. 267-285. - https://doi.org/10.1386/jams.2.3.267_1.

Dekker R., Engbersen G., Klaver J., Vonk H. (2018): Smart Refugees. How Syrian Asylum Migrants Use Social Media Information in Migration Decision-Making. In: Social Media + Society, 4 (1), 11 pages (online only). - https://doi.org/10.1177/2056305118764439. 
FaraJ S., Azad B. (2012): The Materiality of Technology. An Affordance Perspective. In: LeOnardi P. M., NARDi B. A., Kallinikos J. (eds.): Materiality and Organizing. Oxford: Oxford University Press, pp. 237-258.

Frouws B., Brenner Y. (2019): Hype or Hope? Evidence on Use of Smartphones \& Social Media in Mixed Migration. Geneva: Mixed Migration Centre MMC). - http://www.mixedmigration. org/articles/hype-or-hope-new-evidence-on-the-use-of-smartphones-and-social-media-inmixed-migration/ (last access: May 2020).

Gibson J. J. (1979): The Ecological Approach to Visual Perception. Boston: Houghton Mifflin.

Giddens A. (1984): The Constitution of Society. Outline of the Theory of Structuration. Cambridge: Polity Press.

Goffman E. (1986): Frame Analysis. An Essay on the Organization of Experience. Boston: Northeastern University Press.

Gordano Peile C., Ros Hísar A. (2016): Immigrants and Mobile Phone Uses. Spanish-speaking Young Adults Recently Arrived in London. In: Mobile Media \& Communication, 4 (3), pp. 405-423. - https://doi.org/10.1177/2050157916655375.

Greiner C., Sakdapolrak P. (2013): Translocality. Concepts, Applications and Emerging Research Perspectives. In: Geography Compass, 7 (5), pp. 373-384. - https://doi.org/10.1111/ gec3.12048.

Harney N. (2013): Precarity, Affect and Problem Solving with Mobile Phones by Asylum Seekers, Refugees and Migrants in Naples, Italy. In: Journal of Refugee Studies, 26 (4), pp. 541-557. - https://doi.org/10.1093/jrs/fet017.

Hutchiy I. (2001): Technologies, Texts and Affordances. In: Sociology, 35 (2), pp. 441-456. https://doi.org/10.1177/S0038038501000219.

ITU - International Telecommunication Union (2020): Time Series of ICT Data for the World. - https://www.itu.int/en/ITU-D/Statistics/Documents/statistics/2019/ITU_Key_2005-2019_ ICT_data_with\%20LDCs_28Oct2019_Final.xls (last access: April 2020).

Johnson M. C. (2013): Culture's Calling. Mobile Phones, Gender, and the Making of an African Migrant Village in Lisbon. In: Anthropological Quarterly, 86 (1), pp. 163-190. - https://doi. org/10.1353/anq.2013.0002.

Kaufmann K. (2018): Navigating a New Life. Syrian Refugees and Their Smartphones in Vienna. In: Information, Communication \& Society, 21 (6), pp. 882-898. - https://doi.org/10.1080/ $1369118 X .2018 .1437205$.

Kikulwe E. M., Fischer E., QAim M. (2014): Mobile Money, Smallholder Farmers, and Household Welfare in Kenya. In: PloS One, 9 (10), e109804, 13 pages, online only. - https://doi. org/10.1371/journal.pone.0109804.

Kirwin M., Anderson J. (2018): Identifying the Factors Driving West African Migration. Paris: OECD (= West African Papers, 17). - https://www.oecd-ilibrary.org/development/identifying -the-factors-driving-west-african-migration_eb3b2806-en (last access: May 22, 2020)

Kusimba S., Yang Y., Chawla N. (2016): Hearthholds of Mobile Money in Western Kenya. In: Economic Anthropology, 3 (2), pp. 266-279. - https://doi.org/10.1002/sea2.12055.

LAm S. S. K. (2013): ICT's Impact on Family Solidarity and Upward Mobility in Translocal China. In: Asian Journal of Communication, 23 (3), pp. 322-340. - https://doi.org/10.1080/ 01292986.2012 .739186$.

Larsen J., Urry J., Axhausen K. (2008): Coordinating Face-to-face Meetings in Mobile Network Societies. In: Information, Communication \& Society, 11 (5), pp. 640-658. - https://doi.org/ 10.1080/13691180802126752.

Leonardi P. M. (2012): Materiality, Sociomateriality, and Socio-Technical Systems. What Do These Terms Mean? How Are They Different? Do We Need Them? In: Leonardi P. M., 
Nardi B. A., Kallinikos J. (eds.): Materiality and Organizing. Oxford: Oxford University Press, pp. 24-48.

LING R. (1998): The Haves and Have-nots - The Distribution of ICTs in Norwegian Households. In: Telektronikk, 94 (3-4), pp. 102-108.

Ling R. (2004): The Mobile Connection. The Cell Phone's Impact on Society. Amsterdam: Morgan Kaufmann.

Liu P. L., Leung L. (2017): Migrant Parenting and Mobile Phone Use. Building Quality Relationships between Chinese Migrant Workers and their Left-behind Children. In: Applied Research in Quality of Life, 12 (4), pp. 925-946. - https://doi.org/10.1007/s11482-0169498-z.

Lopez L. K. (2017): Always on the Phone. The Invisible Role of Hmong Women in Diasporic Media Industries. In: Communication, Culture \& Critique, 10 (2), pp. 185-202. - https://doi.org/ $10.1111 /$ cccr. 12156

Madianou M. (2012): Migration and the Accentuated Ambivalence of Motherhood. The Role of ICTs in Filipino Transnational Families. In: Global Networks, 12 (3), pp. 277-295. - https:// doi.org/10.1111/j.1471-0374.2012.00352.x.

Madianou M. (2016): Ambient Co-presence. Transnational Family Practices in Polymedia Environments. In: Global Networks, 16 (2), pp. 183-201. - https://doi.org/10.1111/glob.12105.

Madianou M., Miller D. (2011): Mobile Phone Parenting. Reconfiguring Relationships Between Filipina Migrant Mothers and their Left-behind Children. In: New Media \& Society, 13 (3), pp. 457-470. - https://doi.org/10.1177/1461444810393903.

Marcus G. E. (1995): Ethnography in/of the World System. The Emergence of Multi-Sited Ethnography. In: Annual Review of Anthropology, 24 (1), pp. 95-117. - https://doi.org/10.1146/ annurev.an.24.100195.000523.

Nyanhete A. (2017): The Role of International Mobile Remittances in Promoting Financial Inclusion and Development. In: European Journal of Sustainable Development, 6 (2), pp. 256 266. - https://doi.org/10.14207/ejsd.2017.v6n2p256.

OJong N. (2016): Remittances, Mobile Phones and Informality. Insights from Cameroon. In: African Journal of Science, Technology, Innovation and Development, 8 (3), pp. 299-308. https://doi.org/10.1080/20421338.2016.1163478.

Peng Y., Choi S. Y. P. (2013): Mobile Phone Use Among Migrant Factory Workers in South China. Technologies of Power and Resistance. In: China Quarterly, 215, pp. 553-571. - https://doi. org/10.1017/S0305741013000738.

Porter G., Hampshire K., Abane A., Munthali A., Robson E., Tanle A., Owusu S., De Lannoy A., BANGo A. (2018): Connecting with Home, Keeping in Touch. Physical and Virtual Mobility Across Stretched Families in Sub-Saharan Africa. In: Africa, 88 (2), pp. 404-424. https://doi.org/10.1017/S0001972017000973.

QIU J. L. (2014): "Power to the People!" Mobiles, Migrants, and Social Movements in Asia. In: International Journal of Communication, 8, pp. 376-391.

RATHA D. (2003): Worker Remittances: An Important and Stable Source of External Development Finance. In: World Bank (Ed.): Global Development Finance 2003: Striving for Stability in Development Finance. Washington: World Bank, pp. 157-175.

Reckwitz A. (2002): Toward a Theory of Social Practices. In: European Journal of Social Theory, 5 (2), pp. 243-263. - https://doi.org/10.1177/13684310222225432.

Sakdapolrak P., Naruchaikusol S., Ober K., Peth S. A., Porst L., Rockenbauch T., Tolo V. (2016): Migration in a Changing Climate. Towards a Translocal Social Resilience Approach. In: Die Erde. Journal of the Geographical Society of Berlin, 147 (2), pp. 81-94. - https://doi. org/ 10.12854/erde-147-6. 
Schaub M. L. (2012): Lines Across the Desert. Mobile Phone Use and Mobility in the Context of Trans-Saharan migration. In: Information Technology for Development, 18 (2), pp. 126144. - https://doi.org/10.1080/02681102.2011.604082.

Schrock A. R. (2015): Communicative Affordances of Mobile Media: Portability, Availability, Locatability, and Multimediality. In: International Journal of Communication, 9, pp. 1229-1246.

Sekabira H., QAim M. (2017): Mobile Money, Agricultural Marketing, and Off-farm Income in Uganda. In: Agricultural Economics, 48 (5), pp. 597-611. - https://doi.org/10.1111/agec. 12360.

Siegel M., FranSEN S. (2013): New Technologies in Remittance Sending. Opportunities for Mobile Remittances in Africa. In: African Journal of Science, Technology, Innovation and Development, 5 (5), pp. 423-438. - https://doi.org/10.1080/20421338.2013.837287.

Sterly H. (2017): Regionalization Revisited. Mediatization of Translocal Social Practices and the Spatial Reconfiguration of Life in Rural-urban Bangladesh. In: FelgenHAUER T., GäBLER K. (eds.): Geographies of Digital Culture. Abington / New York: Routledge, pp. 52-68.

Sterly H., Gerads D. (2016): "Call Me in the Dorm." Mobile Communication and the Shifting Topographies of Intimate Relationships in Bangladesh. In: Internationales Asienforum, 47 (3-4), pp. 273-296. - https://doi.org/10.11588/iaf.2016.47.3684.

Tazanu P. M. (2015): On the Liveness of Mobile Phone Mediation. Youth Expectations of Remittances and Narratives of Discontent in the Cameroonian Transnational Family. In: Mobile Media \& Communication, 3 (1), pp. 20-35. - https://doi.org/10.1177/2050157914545801.

To S.-M. (2018): Parental Self-esteem, Parent-child Relationships, and Authoritative Parenting of Chinese Migrant Parents of Left-behind Children. Implications for Social Policy and Services. In: Asian Social Work and Policy Review, 12 (3), pp. 183-190. - https://doi. org/10.1111/aswp.12149.

VerTOVEC S. (2009): Transnationalism. London / New York: Routledge.

Wellman B. (2001): Physical Place and Cyberplace. The Rise of Personalized Networking. In: International Journal of Urban and Regional Research, 25 (2), pp. 227-252. - https://doi. org/10.1111/1468-2427.00309.

Zijlstra J., van LiemPt I. (2017): Smart(phone) Travelling. Understanding the Use and Impact of Mobile Technology on Irregular Migration Journeys. In: International Journal of Migration and Border Studies, 3 (2/3), pp. 174-191. - https://doi.org/10.1504/IJMBS.2017.083245. 